\title{
Predictive habitat models derived from nest-box occupancy for the endangered Carolina northern flying squirrel in the southern Appalachians
}

\author{
W. Mark Fordd ${ }^{1, *}$, Andrew M. Evans ${ }^{2}$, Richard H. Odom ${ }^{3}$, Jane L. Rodrigue ${ }^{4}$, \\ Christine A. Kelly ${ }^{5}$, Nicole Abaid ${ }^{6}$, Corinne A. Diggins ${ }^{7}$, Douglas Newcomb ${ }^{8}$ \\ ${ }^{1}$ U.S. Geological Survey, Virginia Cooperative Fish and Wildlife Research Unit, Blacksburg, VA 24061, USA \\ ${ }^{2}$ Department of Geography, Texas Agricultural and Mechanical University, College Station, TX 77843, USA \\ ${ }^{3}$ Geospatial and Environmental Analysis, Virginia Tech, Blacksburg, VA 24061, USA \\ ${ }^{4}$ U.S. Forest Service Northern Research Station, Princeton, WV 24740, USA \\ ${ }^{5}$ North Carolina Wildlife Resources Commission, Asheville, NC 28803, USA \\ ${ }^{6}$ Department of Engineering Science and Mechanics, Virginia Tech, Blacksburg, VA 24061, USA \\ ${ }^{7}$ Department of Fisheries and Wildlife Conservation, Virginia Tech, Blacksburg, VA 24061, USA \\ ${ }^{8}$ U.S. Fish and Wildlife Service, North Carolina Field Office, Raleigh, NC 27606, USA
}

\begin{abstract}
In the southern Appalachians, artificial nest-boxes are used to survey for the endangered Carolina northern flying squirrel (CNFS; Glaucomys sabrinus coloratus), a disjunct subspecies associated with high elevation $(>1385 \mathrm{~m})$ forests. Using environmental parameters diagnostic of squirrel habitat, we created 35 a priori occupancy models in the program PRESENCE for boxes surveyed in western North Carolina, 1996-2011. Our best approximating model showed CNFS denning associated with sheltered landforms and montane conifers, primarily red spruce Picea rubens. As sheltering decreased, decreasing distance to conifers was important. Area with a high probability $(>0.5)$ of occupancy was distributed over 18662 ha of habitat, mostly across 10 mountain ranges. Because nest-box surveys underrepresented areas $>1750 \mathrm{~m}$ and CNFS forage in conifers, we combined areas of high occupancy with conifer GIS coverages to create an additional distribution model of likely habitat. Regionally, above 1385 m, we determined that 31795 ha could be occupied by CNFS. Known occupied patches ranged from $<50$ ha in the Long Hope Valley in North Carolina to approximately 20000 ha in the Great Smoky Mountains National Park along the North Carolina-Tennessee boundary. These findings should allow managers to better define, protect and enhance existing CNFS habitat and provide a basis for future surveys. Owing to model biases, we view this as only a first approximation. Further research combining den selection with foraging habitat use across the full range of elevations, landforms and forest types is needed to increase predictive accuracy of CNFS distribution and sub-population viability.
\end{abstract}

KEY WORDS: Carolina northern flying squirrel - Topographic gradients $\cdot$ Nest-box $\cdot$ Occupancy $\cdot$ Red spruce-Fraser fir · Southern Appalachians

\section{INTRODUCTION}

Managers tasked with conserving endangered species often are handicapped by limited available information on distribution and habitat associations. This often hinders application of full protection meas-

${ }^{*}$ Corresponding author: wmford@vt.edu ures where a species is present and might result in ineffective habitat management efforts when the species is not present. One such Federally endangered species is the Carolina northern flying squirrel (CNFS; Glaucomys sabrinus coloratus), a disjunct subspecies in the southern Appalachians of the

(C) Evans, Odom, Kelly, Abaid, Diggins, and the US Government 2015. Open Access under Creative Commons by Attribution Licence. Use, distribution and reproduction are unrestricted. Authors and original publication must be credited. 
widely distributed northern flying squirrel that inhabits the northern continental portion of the United States through forested areas in Canada and Alaska (Wells-Gosling \& Heaney 1984). Known from 9 isolated mountain peaks or ranges in western North Carolina, eastern Tennessee and southwestern Virginia and believed present in at least 4 more, the mycophagus, cavity- and drey-denning CNFS is primarily associated with mixed northern hardwood-red spruce (Picea rubens), red spruce-Fraser fir (Abies fraseri) and northern hardwood-eastern hemlock (Tsuga canadensis) forests above $1385 \mathrm{~m}$ above sea level (Ford et al. 2007b). As a post-Pleistocene relict restricted to these high-elevation 'sky-islands', the habitat of the naturally rare CNFS was further fragmented and altered by exploitative logging and widespread forest burning in the late $19^{\text {th }}$ through mid-20th century (Weigl 2007). Moreover, this reduced habitat extent in remaining montane boreal forests and/or those in the process of successional recovery are now threatened by exotic insect pests, atmospheric deposition, climate change and continued fragmentation processes (Nowacki et al. 2010, Kelly et al. 2013). An additional threat to CNFS is den-site competition from the local upslope expansion of the southern flying squirrel (Glaucomys volans) occurrence since the exploitative logging era. Following forest disturbance, there was a concomitant increase in hard-mast tree species such as oak Quercus spp. and American beech Fagus grandifolia that have provided energy-rich foods enabling southern flying squirrels to better withstand winter conditions in these high-elevation forests (Weigl et al. 1999, Ford et al. 2007b). Additionally, the presence of southern flying squirrels has resulted in parasite-mediated competition from the intestinal nematode Strongyloides robustus, thought to be detrimental to CNFS populations, whereas southern flying squirrel populations exhibit some resistance (Krichbaum et al. 2010).

Cryptic and difficult to live-trap, CNFS and the recently de-listed Virginia northern flying squirrel (VNFS; Glaucomys sabrinus fuscus; 78 Federal Register 140220-14023), have been monitored primarily by state and federal agencies using nest-box surveys (Stihler et al. 1995, Reynolds et al. 1999, Weigl et al. 1999, McGrath \& Patch 2003, Ford et al. 2010). Nestboxes provide artificial dens that CNFS may use in appropriate habitat due to their largely arboreal, tree-cavity denning behavior (Ford et al. 2007b). In the southern Appalachians, nest-boxes were established in collective transects consisting of 10 to 20 wooden denning structures placed in trees and spaced 30 to $100 \mathrm{~m}$ apart to ascertain the presence of
CNFS (Reynolds et al. 1999, McGrath \& Patch 2003). Surveyed annually, individual nest-boxes and/or their collective transects have provided limited demographic data, such as timing of reproduction for CNFS or VNFS. However, because of limited recaptures, no mark-recapture data sufficient for making population inferences exist (Ford et al. 2010, 2012). In western North Carolina, rugged topography and poor access have limited establishment of survey transects. Occupancy data have been collected at approximately 1000 nest-boxes over the past $20 \mathrm{yr}$, but only a few transects have been established in each of the high-elevation mountain ranges where habitat quality is highest and CNFS are believed to occur more frequently. Moreover, many of the sampled transects were placed in lower elevation, suboptimal habitat as regulatory clearance survey efforts prior to land management activities targeted towards other resource needs. Nonetheless, over a span of 2 decades, annual monitoring of nest-box transects and subsequent analysis of presence-absence data have shown that, within the southern Appalachians, CNFS occupancy appears to be stable to slightly increasing in surveyed habitats (Ford et al. 2012, North Carolina Wildlife Resources Commission unpubl. data).

Analyses of nest-box data in the central Appalachians with VNFS have been used to relate presenceabsence measures to forest-stand-level micro-habitat measures, such as importance values and stocking primarily of red spruce (Ford et al. 2004), and mesoscale environmental factors, such as elevation and landform resulting in predictive models of habitat suitability and distribution (Odom et al. 2001, Menzel et al. 2006a). In the absence of empirical observations of squirrel presence for extensive areas where nestbox transects have not been established, these models are useful tools that allow resource managers to better understand habitat requirements and implement conservation strategies on a landscape scale. For example, in the central Appalachians, predictive habitat models are currently used to prioritize areas for red spruce restoration efforts, in order to enhance the quality of presumed habitat and connect patches of currently suitable squirrel habitat (Rentch et al. 2007).

Similar modeling efforts for CNFS in the southern Appalachians have been limited to 2 mountain ranges in North Carolina, the Great Balsams Mountains and the Black Mountains, but were useful in assessing the relative value of hardwood-dominated habitats at the lower elevation range of CNFS (McGrath \& Patch 2003, North Carolina Wildlife 
Resources Commission unpubl. data). This work illustrated that when CNFS are found in 'marginally suitable' hardwood forests below the montane boreal forest zone, some red spruce component is always present in the local landscape. Still, inferences drawn were limited by equivocal results overall and were not scalable to the larger CNFS distribution in the spatially explicit manner that was possible for the models produced for VNFS. Herein, we report an occupancyderived predictive CNFS model for the southern Appalachians across North Carolina, Tennessee and Virginia using an a priori information-theoretic approach developed using the complete North Carolina nest-box dataset and a larger array of habitat- and landscape-specific environmental and physical variables.

\section{MATERIALS AND METHODS}

\section{Study area}

We examined CNFS nestbox presence-absence capture data assem-

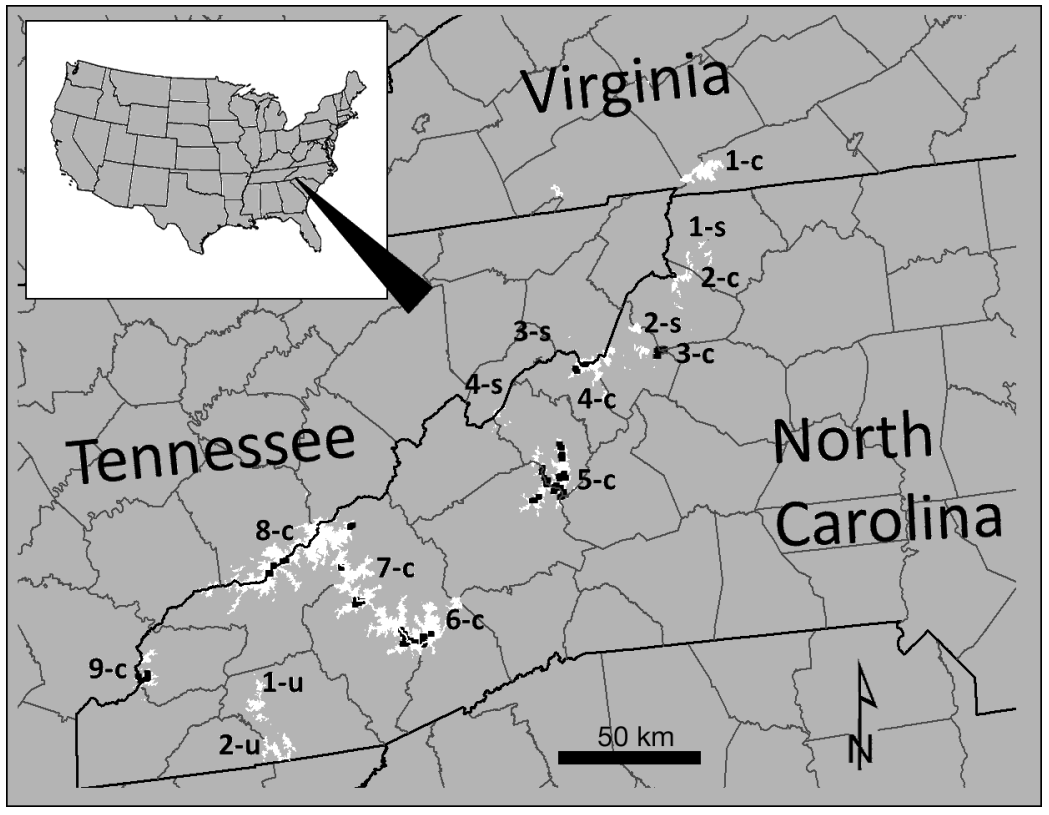

Fig. 1. Areas above $1385 \mathrm{~m}$ (white) in the southern Appalachians of North Carolina, Tennessee and Virginia, USA, where the potential for Carolina northern flying squirrel (CNFS, Glaucomys sabrinus coloratus) habitat exists. Black rectangles represent nest-box survey lines, 1996-2011 in North Carolina. Areas where CNFS have been confirmed: 1-c, Mount Rogers-Whitetop; 2-c, Long Hope Valley; 3-c, Grandfather Mountain; 4-c, Roan Mountain; 5-C, Black and Craggy Mountains; 6-c, Great Balsam Mountains; 7-c, Plott Balsam Mountains; 8-c, Great Smoky Mountains; 9-c, Unicoi Mountains. Areas where CNFS are suspected: 1-s, Pond Mountain; 2-s, Beech/Sugar Mountains; 3-s, Unaka Mountain; 4-s, Big Bald. Areas not surveyed for CNFS but with areas >1385 m:1-u, Wayah Bald; 2-u, Highlands/Scaly Mountain

bled from North Carolina Wildlife

Resources Commission surveys conducted from 1996 to 2011 (Ford et al. 2012). Eighty nest-box transects of 10 to 20 individual boxes were scattered across 7 mountains or ranges: Grandfather Mountain, Roan Mountain, the Black and Craggy Mountain range, the Great Balsam Mountain range, the Plot Balsam range, the Great Smoky Mountain range and the Unicoi range in western North Carolina (Fig. 1). All transects were within the Blue Ridge Mountains subphysiographic province of the southern Appalachian Mountains (Fenneman 1938). Duration of sampling was variable, with some transects monitored annually for the entire $16 \mathrm{yr}$, whereas other lines were surveyed for fewer years. No transects monitored $<3 \mathrm{yr}$ were included in our analyses. Nest-boxes typically were surveyed once a year during the winter when the possibility of CNFS capture was highest.

Elevation of individual nest-boxes examined ranged from 1385 to $1859 \mathrm{~m}$; however, in this region of the Blue Ridge Mountains some peaks exceed $2000 \mathrm{~m}$. Outside of the Great Smoky Mountains National Park, all transects occurred in largely second- growth forests that were heavily modified by previous land use and numerous other past and current environmental perturbations (Ford et al. 2014). Three forest types dominated our study area: northern red oak Quercus rubra, northern hardwood and montane conifer (red spruce-Fraser fir, or eastern hemlock) along with mixed northern hardwoodmontane conifer patches. At lower elevations and along exposed south-facing side-slopes, forest cover consisted mainly of a 'high-elevation' northern red oak type, with an understory shrub layer of flame azalea Rhododendron calendulaceum and mountain laurel Kalmia latifolia. On sheltered north-facing slopes at lower elevations and throughout at midelevations, northern hardwood forests comprised of yellow birch Betula alleghanensis, American beech, maple Acer spp., yellow buckeye Aeseculus octandra and black cherry Prunus serotina dominated, with scattered conifers such as red spruce and eastern hemlock (Korstian 1937, Odom \& McNab 2000, Simon et al. 2005). The highest elevations are dominated by red spruce and Fraser fir, with Fraser fir 
often forming dense monotypic stands above $1800 \mathrm{~m}$ (White et al. 2012). Rosebay rhododendron ( $R$. maximum) often forms dense understory patches in both northern hardwood and red spruce-Fraser fir forests. In the southernmost range examined, the Unicoi Mountains, the highest elevations were solely northern hardwoods or mixed northern hardwood-eastern hemlock, with no extant red spruce-Fraser fir stands. Throughout the region, past logging and burning allowed oak-dominated forests to successfully replace northern hardwoods at the lower elevations on less mesic slope positions. This also allowed northern hardwoods to partially replace red spruceFraser fir at mid-elevations, creating large areas of mixed forests showing less predictable patterns relative to aspect and elevation than those that might have been encountered prior to human disturbance at the turn of the 20th century (Odom \& McNab 2000). Only at the highest elevations $(>1600 \mathrm{~m})$ do montane boreal conifers remain a relatively intact community type (Pyle \& Schafale 1988).

Regionally, annual precipitation $(>150 \mathrm{~cm})$ is equitably distributed throughout the year. The frost-free growing season typically does not exceed $135 \mathrm{~d}$ (McNab \& Avers 1994). The majority of nest-box transects were on public land, i.e. Nantahala and Pisgah national forests, Great Smoky Mountains National Park, Blue Ridge Parkway, the Cherokee Indian Reservation and Mount Mitchell and Grandfather Mountain state parks, whereas the remainder were on cooperating private lands.

\section{Occupancy modeling}

We created annual presence-absence (binary) datasets for 1001 nest-boxes monitored from 1996 to 2011; incomplete spatial data reduced the number of nest-boxes available for analysis to 836. Details for nest-box survey procedures and CNFS capture can be found in Reynolds et al. (1999), McGrath \& Patch (2003) and Ford et al. (2014). Nest-boxes were georeferenced, allowing us to map them within a geographic information system (ArcGIS 10.1, Environmental Systems Research Institute). We considered CNFS to be present following the capture of any individual irrespective of sex, age, or actual numbers of individuals found within a box. Although nest-boxes within a transect were often relatively close, we assumed independence among nest-boxes because CNFS and the similar VNFS do not appear overly territorial, use multiple dens and display overlapping home ranges (Menzel et al. 2004, 2006b, Ford et al.
2014). Previous research by the authors (Odom \& McNab 2000, Odom et. al. 2001) and others (Whittaker 1956, Busing et al. 1993, Bolstad et al. 1998, Ulrey 1999, Simon et. al. 2005) have shown that topographic characteristics such as elevation, landscape position and aspect are important determinants of tree species composition and distribution in many high-elevation southern Appalachian forest landscapes. Therefore, we calculated elevation (m), aspect (degrees azimuth) and an index of topographic exposure (TEI) to include as variables in CNFS occupancy models. All terrain variables were derived from US Geological Survey $1 / 3$ arc-second (10 $\mathrm{m}$ resolution) digital elevation models (DEM; Gesch et al. 2002, Gesch 2007) using the Spatial Analyst Toolbox within ArcGIS. Aspect was linearized using the formula [1 - cosine (aspect)] $+[1$ - sine (aspect)], which produces minimum values for northeast aspects and maximum values for southwest aspects (Odom et al. 2001). Topographic exposure was derived by subtracting the average elevation of an area (defined as a circular area with radius equal to $1000 \mathrm{~m}$ ) surrounding each nest-box from the elevation at each box (Evans et al. 2014). Relatively high TEI values (approximately $>50$ ) indicate that boxes were located on exposed peaks or ridges, whereas low values (approximately $<50$ ) indicate that boxes were located on sheltered landforms such as coves and lower slopes.

We acquired land cover data from the Southeast Gap Analysis Program that were classified from $30 \mathrm{~m}$ resolution Landsat Thematic Mapper imagery collected from 1999 to 2001 (www.basic.ncsu.edu/segap/; NatureServe 2007), and assigned to each nest-box the distance to the nearest red spruce-Fraser fir or eastern hemlock (combined and classified as montane conifer herein) stand, the nearest northern hardwood stand and the nearest montane northern red oak stand. We designated nest-boxes occurring in either montane conifer or northern hardwood (distance value $=0 \mathrm{~m}$ ) stands that were also within $100 \mathrm{~m}$ of the other forest type as a mixed montane conifernorthern hardwood ecotone. We further divided montane conifers as being either structurally 'mature' or not, by combining our vegetation classifications with forest canopy height values derived from a $22.8 \mathrm{~cm}$ vertical resolution LiDAR (light detection and ranging) dataset developed by the US Fish and Wildlife Service, North Carolina Field Office (Newcomb 2012). Mature montane conifer forests were defined as those with canopy heights $>20 \mathrm{~m}$, or two-thirds the minimum height value observed in uncut, oldgrowth red spruce forests in the southern Appalachians (Minckler 1945). 
We created 35 a priori variants of the occupancy, colonization, extinction and detection $[\psi(),. \gamma(),. \varepsilon(),. \rho()$. model in program PRESENCE, Version 2.2 (US Geological Survey, Patuxent, MD), to examine relationships between CNFS occupancy relative to a suite of physical and environmental variables that were available or derivable from existing spatial datasets based on previous modeling attempts or post hoc discussion points from existing literature for CNFS and, also for the VNFS, in an information-theoretic approach (Burnham \& Anderson 2002). These nestbox models were: (1) distance to ecotone forests of admixtures of red spruce and northern hardwood communities (Weigl \& Osgood 1974), (2) distance to montane conifers (Ford et al. 2004), (3)TEI, aspect and elevation (Odom \& McNab 2000, McGrath \& Patch 2003), (4) TEI and distance to montane conifers (Odom \& McNab 2000, Odom et al. 2001), (5) elevation and distance to montane conifers (Menzel et al. 2006a) and (6) distance to montane conifers with mean canopy height $>20 \mathrm{~m}$ (Ford et al. 2014). For model selection, we used an Akaike information criterion (AIC) approach retaining models that were within 4 AAIC units from the best-approximating model (Burnham \& Anderson 2002). We then took the best-approximating model's logistic equation and created a predictive map for the region using the study area's terrain rasters and the raster package (Hijmans \& van Etten 2012) in the statistical software $\mathrm{R}$ ( $\mathrm{R}$ Core Team 2013) that executed the model on a cell-by-cell basis. Using the ArcGIS Spatial Analyst Toolbox, we reclassified the range of values and only retained cells in which CNFS occupancy was probable at $\psi \geq 0.5$. Our nest-box monitoring effort oversampled lower and mid-elevation ranges. Similarly, CNFS foraging data from telemetric observations showed red spruce-Fraser fir to be selected more than would be suggested by availability from a densite-only examination at the second or third order of selection (Ford et al. 2014). Therefore, we created a second layer showing the combined extent of areas of $\psi>0.5$ and other montane conifers, i.e. primarily red spruce-Fraser fir patches on exposed highelevation sites not overlain previously by that occupancy probability.

\section{RESULTS}

Over the years examined, CNFS presence occurred during at least 1 sampling event at 184 of the 836 nest-boxes surveyed. Of the 35 a priori models tested, the best-approximating model was the $\psi$ (TEI + distance to montane conifers), $\gamma$ (TEI + distance to montane conifers), $\varepsilon(),. \rho($.$) variant of the Odom et al.$ (2001) model (Tables 1 \& 2). Increasing CNFS occupancy was positively related to decreasing distance to montane conifer forests and decreasing (sheltered) topographic exposure (Fig. 2). Only 2 other models, also variants of the Odom et al. (2001) model, were within $4 \triangle$ AIC units (Table 1). Beyond these, other tested models that included variables such as elevation, distance to northern hardwood-montane conifer ecotones or forest height/maturity had little empirical support. The next best-performing model after those with empirical support was a variant of the Ford et al. (2014) model relating distance to montane conifer forests $>20 \mathrm{~m}$ in height to occupancy. This mode was $\Delta 14.95$ AIC units from the best-approximating model.

The total area where CNFS $\psi$ was $>0.5$ in the 3 states was approximately 18353 ha (Table 3 ). When additional montane conifer acreage was combined with area where CNFS $\psi>0.5$, there were approximately 31784 ha of CNFS habitat in the region

Table 1. Occupancy, detection probability and Akaike's information criterion (AIC) ranking of best-approximating $\psi(),. \gamma(),. \varepsilon($.$) ,$ $\rho($.) (initial occupancy, local colonization, extinction and detection) models and competing models with empirical support for Carolina northern flying squirrel (Glaucomys sabrinus coloratus) presence-absence data using nest-box surveys in North Carolina, USA, 1996-2011. All 3 models with empirical support were those derived from Odom et al. (2001) and McGrath \& Patch (2003), with topographic exposure index (TEI) and distance to montane conifers (red spruce Picea rubens-Fraser fir Abies fraseri or eastern hemlock Tsuga canadensis) as explanatory variables. Remaining models that were not $<4 \Delta$ AIC units from the best-approximating model are not shown

\begin{tabular}{|c|c|c|c|c|c|c|c|}
\hline Model & Occupancy $(\psi)$ & Colonization $(\gamma)$ & Extinction $(\varepsilon)$ & Detection probability $(\rho)$ & AIC & $\Delta \mathrm{AIC}$ & AICwt \\
\hline 1 & $\begin{array}{l}\text { TEI \& montane } \\
\text { conifers }\end{array}$ & $\begin{array}{l}\text { TEI \& montane } \\
\text { conifers }\end{array}$ & $\begin{array}{l}\text { TEI \& montane } \\
\text { conifers }\end{array}$ & . & 2799 & 0 & 0.57 \\
\hline 2 & $\begin{array}{c}\text { TEI \& montane } \\
\text { conifers }\end{array}$ & . & $\begin{array}{l}\text { TEI \& montane } \\
\text { conifers }\end{array}$ & $\begin{array}{l}\text { TEI \& montane } \\
\text { conifers }\end{array}$ & 2801 & 1.64 & 0.26 \\
\hline 3 & $\begin{array}{l}\text { TEI \& montane } \\
\text { conifers }\end{array}$ & . & $\begin{array}{l}\text { TEI \& montane } \\
\text { conifers }\end{array}$ & . & 2802 & 2.38 & 0.17 \\
\hline
\end{tabular}


Table 2. Parameter estimates for the best-approximating model for Carolina northern flying squirrel (Glaucomys sabrinus coloratus) presence-absence data using nest-box surveys in North Carolina, USA, 1996-2011, with topographic exposure index (TEI) and distance to montane conifers (red spruce Picea rubens-Fraser fir Abies fraseri or eastern hemlock Tsuga canadensis) as explanatory variables

\begin{tabular}{|lcc|}
\hline Covariate & Estimate & Standard error \\
\hline Occupancy $(\psi)$ & & \\
Intercept & -0.2060 & 0.5026 \\
TEI & -0.0180 & 0.0077 \\
Montane conifers & -0.0146 & 0.0068 \\
Colonization $(\gamma)$ & & \\
Intercept & -3.3018 & 0.1603 \\
TEI & -0.0043 & 0.0018 \\
Montane conifers & -0.0001 & 0.0008 \\
Extinction $(\varepsilon)$ & & \\
Intercept & -1.4628 & 0.2155 \\
Detection probability $(\rho)$ & & \\
Intercept & -0.6794 & 0.1628 \\
\hline
\end{tabular}

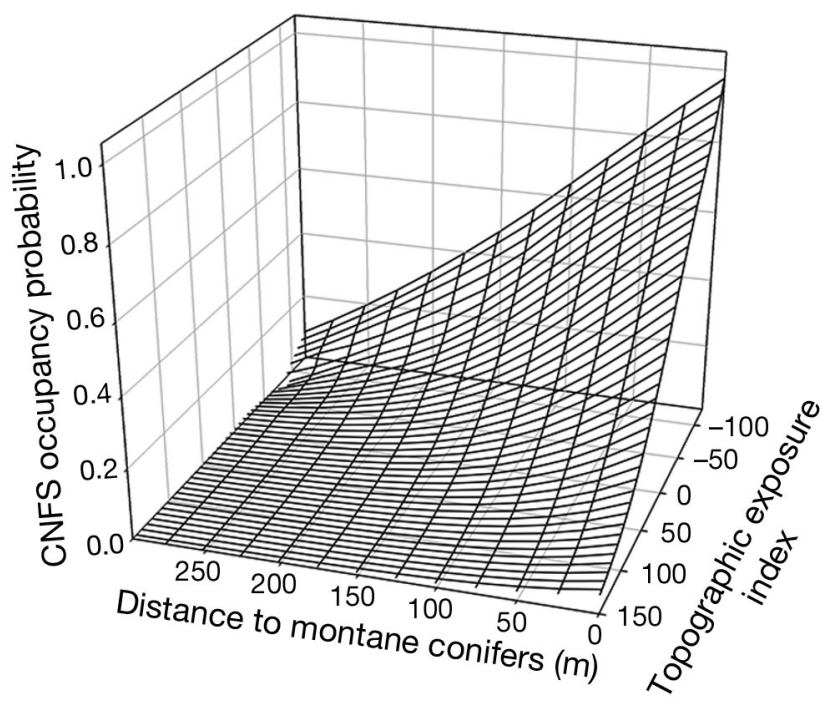

Fig. 2. Relationship between predicted Carolina northern flying squirrel (CNFS; Glaucomys sabrinus coloratus) occupancy from presence-absence data using nest-box surveys in North Carolina, USA, 1996-2011, with topographic exposure and distance to montane conifers (red spruce Picea rubens-Fraser fir Abies fraseri or eastern hemlock Tsuga canadensis) as explanatory variables

(Table 3, Fig. 3). The largest area of CNFS habitat $(\psi>$ 0.5 + other montane conifers) generally occurred in North Carolina, with 23204 ha (Table 3), and specifically in the Great Smoky Mountains along the North Carolina-Tennessee line, with 19708 ha (Fig. 3). Outside of the Great Smoky Mountains, areas of the known occupied mountain ranges and massifs as confirmed by nest-box occupancy or trapping records
Table 3. Areas (ha) above $1385 \mathrm{~m}$, predicted areas of Carolina northern flying squirrel (CNFS; Glaucomys sabrinus coloratus) occupancy $(\psi)>0.5$ and predicted areas of CNFS occupancy $(\psi)>0.5+$ montane conifer areas of red spruce Picea rubens-Fraser fir Abies fraseri not incorporated in the best-approximating model using nest-box surveys in North Carolina, Tennessee and Virginia, USA, 1996-2011 (see 'Results' section)

\begin{tabular}{|lrrc|}
\hline State & $>1385 \mathrm{~m}$ & $\psi>0.5$ & $\begin{array}{c}\psi>0.5+ \\
\text { montane conifer }\end{array}$ \\
\hline North Carolina & 90133 & 13369 & 23210 \\
Tennessee & 14273 & 4740 & 7923 \\
Virginia & 4602 & 244 & 651 \\
\hline
\end{tabular}

were as follows: 4647 ha in the Black and Craggy Mountains, 3651 ha in the Balsam Mountains, 1074 ha in the Plott Balsam Mountains, 680 ha on Grandfather Mountain, 674 ha on Roan Mountain, 651 ha on Mount Rogers-Whitetop, 239 ha in the Unicoi Mountains and $<50$ ha in the Long Hope Valley area (Fig. 3). Numerous other small areas with potential CNFS habitat occurred in the region, including the Pond Mountain, Sugar Mountain, Unaka Mountain and Big Bald areas (Fig. 3), where strong lines of evidence from camera trapping and acoustic monitoring suggest that CNFS occur (Gilley 2013, C. Kelly unpubl. data).

\section{DISCUSSION}

Our use of occupancy, dependent upon vegetation community and topographic parameters, has provided the first quantitative CNFS range-wide distribution model for the southern Appalachians. As such, it provides a probabilistic approach to the presence of CNFS in relation to topographic gradients and proximity to high-elevation conifer cover, primarily red spruce-Fraser fir forests. At the lower and warmer end of the species' apparent elevation range $(1350 \mathrm{~m})$, sheltered, mesic landforms provide the best relative conditions favorable to CNFS, such as cooler microclimates, greater soil organic depth and presumably better production of hypogeal fungal foods (Odom et al. 2001, Ford et al. 2007a,b). Similarly, as elevations increase and landforms become more exposed, CNFS are more associated with red spruce-Fraser fir stands, where hypogeal fungal presence is high and the production of high-energy hard mast, i.e. acorns, that would support the competing southern flying squirrels correspondingly is low (Loeb et al. 2000). More importantly, our observations provide managers with greater confidence about the location or assumed 


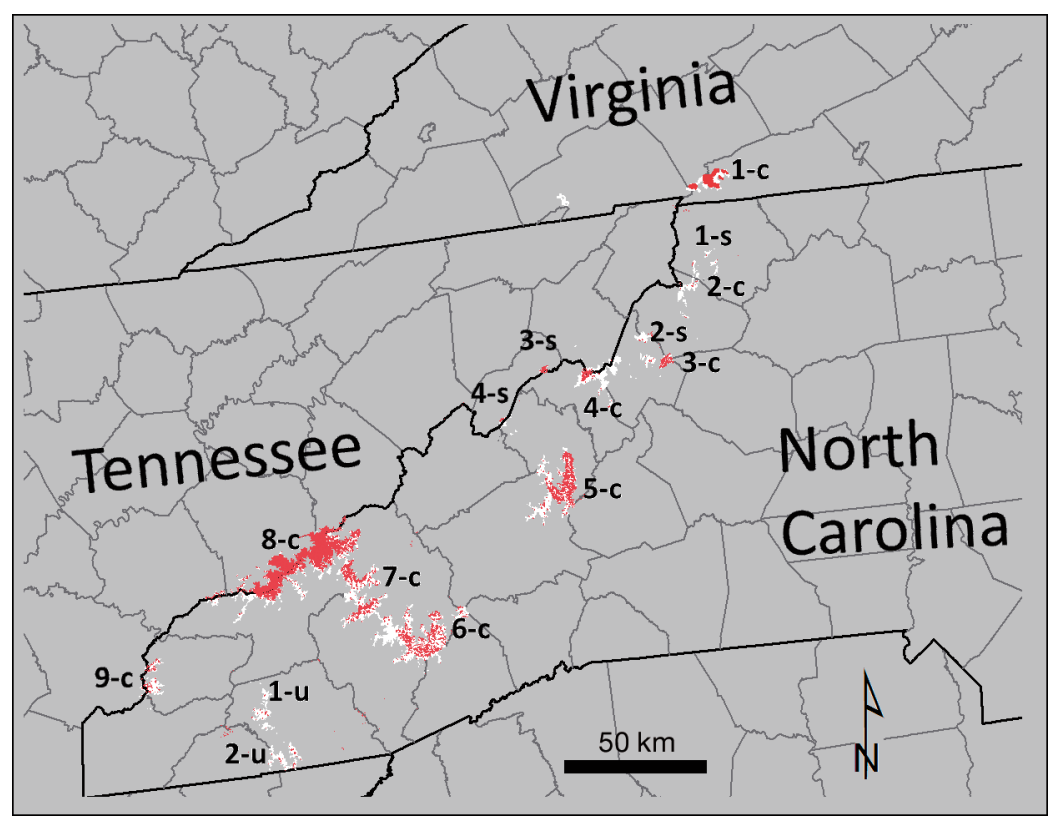

Fig. 3. Areas (in red) above $1385 \mathrm{~m}$ in the southern Appalachians of North Carolina, Tennessee and Virginia, where predicted Carolina northern flying squirrel (Glaucomys sabrinus coloratus) occupancy $(\psi)>0.5+$ montane conifers (area of red spruce Picea rubens-Fraser fir Abies fraseri or eastern hemlock Tsuga canadensis). For area details see Fig. 1 legend

presence of CNFS in the landscape and when prioritizing areas for conducting acoustical surveys (Gilley 2013). This could be done now without having to either maintain annual monitoring of large numbers of nest-box transects or establish new transects for land management regulatory clearance-tasks that require considerable logistical effort and expense. In that same vein, however, our findings would indicate a need to conduct additional surveys in areas heretofore not surveyed but where some patches of moderate predicted occupancy values occur, i.e. $\psi>10 \%$ but $<50 \%$. Clearly, CNFS are persisting in portions of the southern Appalachians where the perceived extent of habitat is smaller (<300 ha) than what is believed necessary to maintain population viability of other northern flying squirrel subspecies in North America (Smith 2007). Therefore, CNFS presence in the more isolated massifs with some suitable habitat is not discountable where the combination of high-elevation and/or sheltered landforms are sufficient to support northern hardwood communities with a montane conifer component. For example, these areas might include eastern hemlock patches in extreme southwestern North Carolina and southeastern Tennessee where red spruce-Fraser fir are absent).

Our results are largely in concurrence with McGrath \& Patch's (2003) examination of CNFS in the Great Balsam Mountains, which used an absolute presence-absence logistic regression approach to analyze nest-box captures to model presence in the local landscape. Using predicted forest type maps developed by Odom \& McNab (2000), McGrath \& Patch (2003) observed a high proportion of CNFS presence in predicted high-quality red spruce-northern hardwood habitats. Moreover, these habitats accounted for the majority of total captures as well. However, the authors also captured a few individuals (but with few or no multi-year re-captures) at sites with predicted northern red oak dominance, thereby concluding that their model had a high correct specificity for the red spruce-northern hardwood type, but an overall lower sensitivity for excluding non-occupied habitats. Our model overcomes this by assigning a low predicted occupancy probability to nest-boxes in northern red oak that might also have a favorable, sheltered landform position or otherwise had some spatial proximity to montane conifers. Accordingly, our results could be used to provide an improved method to value the contribution of lower elevation northern hardwood stands $(\psi=10-50 \%)$ as potential corridor/connecting forests between montane conifer patches and those that are either uninhabitable by CNFS or that serve as deleterious sink habitats.

Our occupancy model also has the potential to be used by resource managers wanting to prioritize areas to improve the condition or amount of red spruce-Fraser fir stands based on the thinning and crop-tree release techniques being used in the central Appalachians (Schuler et al. 2002, Rentch et al. 2007). As such, preference could be given to those sites that are currently northern red oak or northern hardwood with more sheltered landforms or that are in closer proximity to extant montane conifers. This could increase the area of occupied CNFS habitat, while also possibly decreasing the area of suitable southern flying squirrel habitat. Additionally, priority should be given to enhancing red spruce-Fraser fir stands at sites where climate-change models suggest that red spruce-Fraser fir has the best chance to persist long term with the predicted climate change for the region (Potter et al. 2010). Where northern red oak communities are maintained or restored with 
prescribed fire (Brose et al. 2001), managers now can use this model to avoid stands with higher predicted CNFS occupancies and concentrate oak management on areas where CNFS predicted occupancy is low, i.e. $\psi<10 \%$. Similarly, areas where montane conifers are comprised mainly or exclusively of eastern hemlock, emphasis could be placed on ascertaining the impact of eastern hemlock mortality from hemlock wooly adelgid Adelges tsugae, where CNFS occur.

However, our model of potential CNFS occupancy was based solely on the species' denning habitat; therefore, our results should be interpreted cautiously and used only as a first-cut approximation. For example, the CNFS is closely tied to highelevation habitats, yet no a priori model containing elevation received empirical support. Despite elevations in the region $>2000 \mathrm{~m}, 90 \%$ of nest-boxes analyzed were located $<1750 \mathrm{~m}$. Moreover, based on previous surveys and records of occurrence, our lower threshold of analysis was set at $1385 \mathrm{~m}$, meaning, in practice, that our analyses examined data concentrated largely in a narrow elevation band. Historically, much of the early CNFS research occurred within this elevation band along ecotone habitats (Weigl et al. 1999) and then later focused on lower elevation distributions of CNFS (McGrath \& Patch 2003). Also, for both CNFS and the VNFS in the central Appalachians, many past monitoring efforts were targeted towards areas along the northern hardwood and montane conifer ecotone for endangered species assessment efforts prior to the onset of US Forest Service land management activities (Stihler et al. 1995, Menzel et al. 2006b, Ford et al. 2010, 2014). Because little or no forest management has occurred at higher elevations, where pure red spruce-Fraser fir forests dominate, little survey effort was exerted in those habitats-introducing an inherent bias in our modeling effort. Despite foraging preferentially in red spruce-Fraser fir patches (Ford et al. 2014), abundant denning sites presently occur in second-growth mixed stands with copious yellow birch cavity trees/snags at mid-elevations, so cosmopolitan occupancy from $1385 \mathrm{~m}$ and above is highly probable (Kelly \& Ford 2010). Whether or not this is a function solely of current post-disturbance conditions, successional trajectories, or local community amalgamation could be tested by conducting CNFS surveys where substantial amounts of both old-growth northern hardwood and red spruceFraser fir forests can be compared at the same elevation, i.e. in Great Smoky Mountains National Park. Efforts researching den choice and foraging habitat selection to develop more precise functional models of resource selection are currently ongoing and are concentrated within pure red spruce-Fraser fir forests at the highest elevations in North Carolina and Virginia (C. Diggins unpubl. data). These data should provide greater insight into CNFS distribution, habitat selection and, perhaps, the management of future threats.

Acknowledgements. The funding of our study was provided by the US Fish and Wildlife Service Region 4, Asheville, North Carolina Field Office, US Geological Survey Cooperative Research Units program, North Carolina Wildlife Resources Commission and Virginia Department of Game and Inland Fisheries. The use of any trade, product, or firm name does not imply endorsement by the US government.

\section{LITERATURE CITED}

Bolstad PV, Swank W, Vose J (1998) Predicting southern Appalachian overstory vegetation with digital terrain data. Landscape Ecol 13:271-283

Brose P, Schuler T, Van Lear D, Berst J (2001) Bringing fire back: the changing fire regimes of the Appalachian mixed-oak forests. J For 99:30-35

Burnham KP, Anderson DR (2002) Model selection and inference: a practical information-theoretic approach, $2^{\text {nd }}$ edn. Springer-Verlag, New York, NY

Busing RT, White PS, MacKenzie MD (1993) Gradient analysis of old spruce-fir forests of the Great Smoky Mountains circa 1935. Can J Bot 71:951-958

Evans AN, Odom RH, Resler L, Ford WM, Prisley S (2014) Developing a topographic model to predict the northern hardwood forest type within Carolina northern flying squirrel (Glaucomys sabrinus coloratus) recovery areas of the southern Appalachians. Int J For 2014:179415, doi: 10.1155/2014/179415

Fenneman NM (1938) Physiography of eastern United States. McGraw-Hill Book Company, New York, NY

US Fish and Wildlife Service (1990) Appalachian northern flying squirrel (Glaucomys sabrinus fuscus and Glaucomys sabrinus coloratus) recovery plan. USDI Fish and Wildlife Service, Newton Corner, MA

Ford WM, Stephenson SL, Menzel JM, Black DR, Edwards JW (2004) Habitat characteristics of the endangered Virginia northern flying squirrel (Glaucomys sabrinus fuscus) in the Central Appalachians. Am Midl Nat 152: $430-438$

Ford WM, Mertz KN, Menzel JM, Sturm KK (2007a) Winter home range and habitat use of the Virginia northern flying squirrel (Glaucomys sabrinus fuscus). USDA Forest Service Res Pap NRS-4, Northern Research Station, Newtown Square, PA

Ford WM, Rodrigue JL, Chapman BR (2007b) Northern flying squirrel. In: Trani-Griep M, Ford WM Chapman BR (eds) Land manager's guide to mammals of the South. The Nature Conservancy, Durham, NC, p 389-394

Ford WM, Moseley KR, Stihler CW, Edwards JW (2010) Area occupancy and detection probabilities of the Virginia northern flying squirrel (Glaucomys sabrinus fuscus) 
using nest-box surveys. In: Rentch JS, Schuler TM (eds) Proceedings from the conference on the ecology and management of high elevation forests in the central and southern Appalachian Mountains. USDA Forest Service Gen Tech Rep NRS-P-64, Northern Research Station, Newtown Square, PA, p 37-47

Ford WM, Evans A, Odom RH (2012) Preliminary application of occupancy modeling (program PRESENCE) for Carolina northern flying squirrels. Report to North Carolina Wildlife Resources Commission, Asheville, NC

Ford WM, Kelly CA, Rodrigue JL, Odom RH, Newcomb D, Gilley LM, Diggins CA (2014) Late winter and early spring home range and habitat use of the endangered Carolina northern flying squirrel in western North Carolina. Endang Species Res 23:73-82

Gesch DB (2007) The national elevation dataset. In: Maune D (ed) Digital elevation model technologies and applications: the DEM user's manual, 2nd edn. American Society for Photogrammetry and Remote Sensing, Bethesda, MD, p 99-118

Gesch DB, Oimoen M, Greenlee S, Nelson C, Steuck M, Tyler D (2002) The national elevation dataset: photogram. Engineer Rem Sens 68:5-11

Gilley LM (2013) Discovery and characterization of high-frequency calls in North American flying squirrels (Glaucomys sabrinus and G. volans): implications for ecology, behavior, and conservation. PhD dissertation, Auburn University, Auburn, AL

Hijmans RJ, van Etten J (2012). Raster: geographic analysis and modeling with raster data. R package Version 2.0-12. http://CRAN.R-project.org/package=raster

Kelly CA, Ford WM (2010) Occupancy rate and detection probability of the Carolina northern flying squirrel in North Carolina. In: Abstracts of the $20^{\text {th }}$ colloquium on conservation of mammals in the southeastern United States. North Carolina Wildlife Resources Commission, Asheville, NC, p 13

Kelly CA, Diggins CA, Lawrence AJ (2013) Crossing structures reconnect federally endangered flying squirrel populations divided for 20 years by road barrier. Wildl Soc Bull 37:375-379

Korstian CF (1937) Perpetuation of spruce on cut-over and burned lands in the higher southern Appalachian Mountains. Ecol Monogr 7:125-167

Krichbaum K, Mahan CG, Steele MA, Turner G, Hudson PJ (2010) The potential role of Strongyloides robustus on parasite-mediated competition between two species of flying squirrels (Glaucomys). J Wildl Dis 46:229-235

Loeb SC, Tainter FH, Cazares E (2000) Habitat associations of hypogeous fungi in the southern Appalachians: implications of the endangered Carolina northern flying squirrel (Glaucomys sabrinus fuscus). Am Midl Nat 144: 286-296

McGrath C, Patch S (2003) Using a terrain-based vegetation model to map Carolina northern flying squirrel distribution. Proc Southeast Assoc Fish Wildl Agenc 57:243-251

McNab WH, Avers PE (1994) Ecological subregions of the United States: section descriptions. Admin Publ WOWSA-5, US Department of Agriculture, Forest Service, Washington, DC

> Menzel JM, Ford WM, Edwards JW, Menzel MA (2004) Nest tree use by the endangered Virginia northern flying squirrel with recommendations for habitat restoration. Am Midl Nat 151:355-368

Menzel JM, Ford WM, Edwards JW, Ceperley L (2006a) A habitat model for the Virginia northern flying squirrel (Glaucomys sabrinus fuscus) in the central Appalachian Mountains. USDA Forest Service Res Pap NE-729, Northeastern Research Station, Newtown Square, PA

> Menzel JM, Ford WM, Edwards JW, Terry TM (2006b) Home range and habitat use of the vulnerable Virginia northern flying squirrel Glaucomys sabrinus fuscus in the central Appalachian Mountains. Oryx 40:204-210

Minckler LS (1945) Reforestation in the spruce type in the southern Appalachians. J For 43:349-356

NatureServe (2007) International ecological classification standard: terrestrial ecological classifications. NatureServe Central Databases, Arlington, VA

> Newcomb D (2012) Using GRASS GIS to model solar irradiation on North Carolina aquatic habitats with canopy data. Trans GIS 16:161-176

Nowacki G, Carr R, Van Dyck M (2010) The current status of red spruce in the eastern United States: distribution, population trends, and environmental drivers. In: Rentch JS, Schuler TM (eds) Proceedings from the conference on the ecology and management of high elevation forests in the central and southern Appalachian Mountains. USDA Forest Service Gen Tech Rep NRS-P-64, Northern Research Station, Newtown Square, PA, p 140-162

Odom RH, McNab WH (2000) Using digital terrain modeling to predict ecological types in the Balsam Mountains of western North Carolina. USDA Forest Service Res Note SE-8, Southern Research Station, Asheville, NC

Odom RH, Ford WM, Edwards JW, Stihler CW, Menzel JM (2001) Developing a habitat model for the endangered Virginia northern flying squirrel (Glaucomys sabrinus fuscus) in the Allegheny Mountains of West Virginia. Biol Control 99:245-252

Potter KM, Hargrove WW, Koch FH (2010) Predicting climate change extirpation risk for central and southern Appalachian forest tree species. In: Rentch JS, Schuler TM (eds) Proceedings from the conference on the ecology and management of high elevation forests in the central and southern Appalachian Mountains. USDA Forest Service Gen Tech Rep NRS-P-64, Northern Research Station, Newtown Square, PA, p 37-47

Pyle C, Schafale MP (1988) Land use history of three spruce-fir forest sites in southern Appalachia. J For Hist 32:4-21

R Core Team (2013) R: a language and environment for statistical computing. R Foundation for Statistical Computing, Vienna. www.R-project.org/

> Rentch JS, Schuler TM, Ford WM, Nowacki GJ (2007) Red spruce stand dynamics, simulations and restoration opportunities in the central Appalachians. Restor Ecol 15: 440-452

Reynolds RJ, Pagels JF, Fies ML (1999) Demography of northern flying squirrels in Virginia. Proc Southeast Assoc Fish Wildl Agenc 53:340-349

Schuler TM, Ford WM, Collins RJ (2002) Successional dynamics and restoration implications of a montane coniferous forest in the central Appalachians. Nat Areas J 22:88-98

Simon SA, Collins TK, Kauffman GL, McNab WH, Ulrey CJ (2005) Ecological zones in the southern Appalachians: first approximation. USDA Forest Service Res Pap SRS41, Southern Research Station, Asheville, NC

Smith WP (2007) Ecology of Glaucomys sabrinus: habitat, demography and community relations. J Mammal 88: 862-881 
Stihler CW, Wallace JL, Michael ED, Pawelczyk H (1995) Range of Glaucomys sabrinus fuscus, a federally endangered subspecies of the northern flying squirrel in West Virginia. Proc W V Acad Sci 67:13-20

Ulrey J (1999) Classification of the vegetation of the southern Appalachians, final report. USDA Forest Service, Southeastern Research Station, Bent Creek Experimental Forest, Asheville, NC

Weigl PD (2007) The northern flying squirrel Glaucomys sabrinus: a conservation challenge. J Mammal 88:897-907

Weigl PD, Osgood DW (1974) Study of the northern flying squirrel, Glaucomys sabrinus, by temperature telemetry. Am Midl Nat 92:482-486

Editorial responsibility: Clive McMahon,

Darwin, Australia
Weigl PD, Knowles TW, Boynton AC (1999) The distribution and ecology of the northern flying squirrel, Glaucomys sabrinus coloratus, in the southern Appalachians. North Carolina Wildlife Resources Commission Project Report, Raleigh, NC

Wells-Gosling N, Heaney LR (1984) Glaucomys sabrinus. Mamm 229(Spec):1-8

White PB, van de Gevel SL, Soule PT (2012) Succession and disturbance in an endangered red spruce-Fraser fir forest in the southern Appalachian Mountains, North Carolina, USA. Endang Species Res 18:17-25

Whittaker RH (1956) Vegetation of the Great Smoky Mountains. Ecol Monog 26:2-80

Submitted: August 25, 2014; Accepted: November 27, 2014 Proofs received from author(s): February 17, 2015 